\title{
Developing eco-innovations: a three-stage typology of supply networks
}

\author{
Samuel Roscoe ${ }^{\mathrm{a},}{ }^{*}$, Paul D. Cousins ${ }^{\mathrm{b}}$, Richard C. Lamming ${ }^{\mathrm{b}}$ \\ a The University of Sussex, School of Business, Management and Economics, Brighton BN1 9SL, United Kingdom \\ ${ }^{\mathrm{b}}$ The University of Manchester, Manchester Business School, Booth Street West, Manchester M15 6PB, United Kingdom
}

\section{A R T I C L E I N F O}

\section{Article history:}

Received 25 April 2014

Received in revised form

9 May 2015

Accepted 26 June 2015

Available online $\mathrm{xxx}$

\section{Keywords:}

Conceptual framework

Sustainability

Supply chain management

Supply networks

Eco-innovation

Industrial networks

\begin{abstract}
A B S T R A C T
This paper uses grounded theory to develop and deepen our understanding of eco-innovation. It presents, through a series of four propositions, a three-stage supply network typology to help scholars and managers consider how best to develop these innovations. This typology was constructed by reviewing existing sustainability frameworks that argued that innovation was a key factor in sustainability. Moreover we found little consideration given on how to discover and develop eco-innovations. The literature proposes that a firm with strong ties with a few strategic suppliers will benefit from the knowledge and technology that spills over from suppliers to the firm during the new product development process. In contrast, the network literature explains that the creation of multiple weak ties to non-strategic suppliers may increase opportunities for identifying innovation. The network literature further suggests a third and potentially more promising route: building weak ties to suppliers that bridge 'structural holes' in the network. We suggest that strong ties with strategic suppliers will lead to the development of incremental eco-innovations while weak ties with multiple suppliers and with suppliers that bridge structural holes will tend to lead to radical eco-innovations. Finally, we suggest that once ecoinnovations are developed they should be embedded in the operational processes of other suppliers to increase the sustainability performance of the focal firm.
\end{abstract}

๑) 2015 Elsevier Ltd. All rights reserved.

\section{Introduction}

The depletion of the Earth's finite resources through increased consumption, industrialisation and globalisation is causing organisations to reconsider how they should compete in the coming years and decades. Specifically, they are concerned with how they add value and compete through the manipulation of their global value chains or more accurately their global supply networks. Simultaneously, consumers are demanding products and services at increasingly competitive prices, pressuring firms to produce goods and services at lower costs while absorbing the financial impacts of increasingly stringent sustainable legislation (Srivastava, 2007). There is a growing pressure on supply chain managers to provide economical and innovative solutions through waste reduction and the development of new 'clean' technologies, in

\footnotetext{
* Corresponding author. Tel.: +44 (0)1273 872668.

E-mail addresses: s.roscoe@sussex.ac.uk (S. Roscoe),paul.cousins@mbs.ac.uk (P.D. Cousins), richard.lamming@mbs.ac.uk (R.C. Lamming).
}

order to support the organisation's goals and strategic objectives and pacify stakeholders (Koplin et al., 2007; Touboulic et al., 2014).

These pressures are derived from the business environment, specifically from a variety of stakeholders that are external, internal and on the fringes of the business. The environment is an increasingly influential driver of change, particularly as the impacts of sustainability issues have a considerable impact on a firm's brand and profitability. The media are awash with examples of prestigious brands, such as Apple, Nike, Body Shop and Tesco being reported for sustainability violations ranging from contamination in food products (the 2013 'horsemeat scandal' in the UK) to slavery and child labour in raw materials production (Copper and Coltan in the Democratic Republic of Congo). These sustainability 'incursions' have the ability to affect a firm's share value severely, damaging brands and threatening business survival (Hendricks and Singhal, 2003).

External stakeholders often hold a firm to account for the environmental and social impacts of internal operations and the operations of its suppliers (Sharma and Henriques, 2005; Krause et al., 2009). Responses to these pressures have typically been 
defensive (tactical rather than strategic), often failing to mobilise resources appropriately in order to build up a strategic competence in sustainability. There are examples of more enlightened proactive firms (see Forbes.com list of 100 most sustainable companies) that have been more strategic in the allocation of resources. These firms appear to view sustainability as a strategic capability rather than as simply a cost to the business. The complexity and global nature of most supply networks makes it difficult to have visibility of all the sustainable implications of doing business (Pagell and Wu, 2009). We therefore suggest that this is a Resource-Based View (RBV) argument. We shall address it using the application and development of the Natural Resource-Based View (NRBV) of the firm, originally proposed by Hart (1995) and recently developed by Hart and Dowell (2011).

We use the definition of sustainable supply chain management provided by Seuring and Muller (2008: 1700), which states that "[sustainable supply chain management] ... is the management of material and information flows as well as cooperation among companies along the supply chain while taking goals from all three dimensions of sustainable development, i.e. economic, environmental and social, and stakeholder requirements into account, which are derived from customer and stakeholder requirements."

By focussing on core competencies and outsourcing parts of the production process, many firms appear to have moved a substantial sustainability burden onto their suppliers. This has a macro level benefit for national governments when supply networks are international, transferring the carbon burdens of production to the supplier's host nation (Klein, 2014). Since such host nations are typically in newly industrialising economies, Western governments appear to be reducing their carbon emissions and at the expense of the developing world, a strategy for offsetting carbon taxes (Klein, 2014). Suppliers of raw materials impact the environment during extraction, manufacturing, and transport processes and affect society through interactions with local communities and the workforce. Attempts have been made in the USA to address this, especially in terms of minerals extractions, via the Dodd-Franks Act 2010. Section 1502 of this act (2013) requires US companies to reveal the sources of their mineral supplies, especially those labelled "conflict." The response of the industry however was principally aimed at delaying or even defeating this law. Legal disputes continue.

Rather than the simplistic, linear supply 'chain' concept, researchers have broadly adopted the terminology of industrial supply 'networks.' An industrial network refers to all of the actors within one industrial sector, or between related industrial sectors, who may cooperate to add value for the consumer (Håkansson and Snehota, 1995; van Bommel, 2011). Many suppliers within networks may have capabilities to develop innovations that address sustainability issues. We build on the concept of eco-innovations prescribed by Carcillo-Hermosilla et al. (2010: 1075) who state that "[eco-innovation is] ... innovation that improves environmental performance." We develop this argument by examining ecoinnovations as a strategic concept that operates within a complex supply network. We argue that these innovations can be product, process and organisational based. In line with the NRBV we suggest that these eco-innovations may fall into one of two categories. Incremental eco-innovations (product stewardship) would include the formation of an agreed standard for sustainable activity, such as the creation of the Marine Stewardship Council, for sustainable fishing. Radical eco-innovations (i.e. clean technologies: see Hart, 1995; Klewitz and Hansen, 2014) would include the development of renewable energy technologies that could replace large parts of the extractive industry.

Process eco-innovations reduce the environmental impact of the manufacturing process by using cleaner production technologies; product eco-innovations ensure products are designed to generate less waste or include renewable energy technologies; and organisational eco-innovations deal primarily with improving working conditions and employee welfare. These can be further segregated into incremental eco-innovations which introduce relatively minor changes to existing products and processes or radical eco-innovations which have the potential to influence the sustainable development of entire industries (Hansen and Große-Dunker, 2013; Klewitz and Hansen, 2014).

Several sustainability frameworks have been introduced over the past fifteen years including: Sustainable Operation Management (Kleindorfer et al., 2005); Green Supply Chain Management (Sarkis, 2003; Zhu and Sarkis, 2004; Rao and Holt, 2005; Cousins et al., 2004); Sustainable Supply Chain Management (Seuring and Muller, 2008; Carter and Rogers, 2008; Pagell and Wu, 2009) and sustainability strategies in industrial supply networks (van Bommel, 2011). All these authors see innovation as a key factor in sustainability yet pay little attention to how firms might find and develop eco-innovations. We argue that sustainability should be embedded as part of the way an organisation conducts its business rather than be seen as something 'in addition' to its general business practices and procedures. We therefore seek to address the question: how can firms develop eco-innovations in industrial supply networks?

By drawing on the RBV (Barney, 1991) and specifically the Extended Resource-Based View (ERBV) (Connor and Prahalad, 1996) and Network Theory (Benkler, 2006; Jones et al., 1997), we advance three routes for developing eco-innovations in industrial supply networks. The first route we term 'tight' collaborations: developing strong ties with strategic suppliers to benefit from the knowledge and technology that 'spill-over' from suppliers to the buying firm during the new product development (NPD) process. We suggest that this route tends to lead to incremental ecoinnovations. The second route, we term 'loose' collaboration: creating multiple weak ties with suppliers. This increases the opportunities for scanning and securing eco-innovations (Lawson et al., 2009). This requires a comprehensive understanding of the supplier network capabilities, requiring high degrees of supplier market intelligence (Cousins, 2005; Handfield and Lawson, 2007; Handfield et al., 2009). The third route we term 'bridging' collaborations: building weak ties with suppliers who bridge structural holes (Burt, 1992) in the network in order to access the novel ideas and technologies that they are likely to possess. We suggest that 'loose' and 'bridging' collaborations will have the tendency to lead to the development of more radical eco-innovations, which are more product than process based. Because of the weak ties associated with such a network, we would expect to see minimal organisational innovations beyond a basic understanding of compliance. Tight collaborations, because of their strong ties, are more likely to lead to more incremental innovations. These will tend to be more process than product focused: e.g. the use of kaizen workshops to improve design processes, reduce waste and speed up throughput times. We would also expect to see more organisational innovations leading to improvements in working conditions though increased visibility of the supply chain, derived through greater stability and therefore knowledge and information sharing. Therefore we suggest that in the eyes of external stakeholders, the sustainability performance of the firm can be improved by the embedding of eco-innovations as a strategic objective into standard procurement management practices.

The remainder of this paper is divided into four sections. The first section describes the conceptual theory-building methodology. In the second section, we make a distinction between chains and networks, explain the importance of innovation in sustainability, and highlight an important gap in existing sustainability 
frameworks. Next, we build a conceptual framework examining the role of eco-innovations in supply networks by advancing four propositions. Finally, we suggest ways to test the propositions empirically, highlight limitations of the framework, and discuss some research and managerial implications.

\section{Theory development: collaborations and eco-innovations}

In this section we begin by developing the theoretical arguments that underpin our framework on eco-innovations. We argue that this is a capabilities-based approach and we build our discussion by using the RBV and ERBV. We then introduce the concept of network theory. Finally, we discuss how this applies to the management of complex supply networks. We conclude by reviewing the literature on supply chain sustainability frameworks and highlighting how our research may add to the current discourse on eco-innovation and supply chain management.

\subsection{Collaboration development and business networks}

Increasing collaborations between business organisations and their suppliers has led many scholars to explore and theorise on how inter-organisational relationships may develop and evolve and ultimately lead to the creation of organisational competitive advantage. The RBV perspective has become an established theoretical lens for scholars to study the firm and its collaborative relationships, as a portfolio of resources that can be combined to create maximum value (Barney, 1991; Prahalad and Hamel, 1990).

Research suggests that these network resource endowments can have a significant impact on rent accumulation and therefore competitive advantage (Gulati, 1999; Arya and Lin, 2007). Arya and Lin (2007: 698) term these 'collaborative networks': networks exhibiting social embeddedness (Granovetter, 1985). They define 'collaborative networks' as: “... a collection of loosely connected or close-knit organisations that share resources" (Arya and Lin, 2007, p. 698). These linkages may help the organisations share a joint strategic objective. In order to gain a better understanding of how these networks evolve, scholars have employed Social network theory (Nohria and Eccles, 1992; Benkler, 2006) as a theoretical lens. The multi-faceted nature of studying networks however presents a variety of problems in terms of focus. The literature can be divided into two distinct streams (Arya and Lin, 2007): external and organisational perspectives.

Some scholars (e.g. Gulati, 1995; Laursen and Salter, 2006) take a predominantly external perspective, focussing on inter-firm linkages that are able to deliver additional value. These may include joint new product development work and innovations, such as collaborations (Cousins et al., 2011; Frohlich and Westbrook, 2001; Lawson et al., 2009). Scholars have also discussed how using 'open innovation' through social networks can drive new ideas and business innovations (Chesbrough, 2004; Chesbrough et al., 2006) and build reputation, leading to higher network profiles and the likelihood of increasingly productive collaborations (Stuart et al. 1999; Yan and Dooley, 2013).

The organisational perspective builds on the work of Granovetter (1985) and Burt (1995, 2000), focussing on the orchestration of resources within a network by the 'focal actor' to achieve superior performance. These include financial resources (Ahuja, 2000) and the ability to coordinate and manage a complex integrated team (Frohlich and Westbrook, 2001). The concept allows for the bridging of structural holes through the organisational coordination of resources, thus enhancing network outcomes.

Social network theory is complementary to the RBV as it allows scholars to analyse the effects of the external and organisational perspectives on the superior allocation of resources between organisations within the network. These joint perspectives are ideal for examining the integration of complex supply networks (Frohlich and Westbrook, 2001; Lawson et al., 2009). To date, there have been few studies combining these frameworks focussing at the organisational level, especially on sustainable supply chains. Our paper positions a theoretical argument that allows scholars to bridge this gap, combining social network theory and RBV to understand how organisations can gain competitive advantage from building a sustainable orientation to their supply chain innovation activities.

\subsection{A resourced-based view of supply network collaboration}

The RBV was initially conceptualised by Penrose (1959) in her seminal work, in which she took an organisational perspective, viewing the organisation as a bundle of heterogeneous resources which depending on how they were combined had the potential to create sustainable competitive advantage (Peteraf, 1993; Wernerfelt, 1984). The concept of resources was further developed by Barney $(1991,2001)$ and defined as both tangible e.g. machinery, buildings, technology and intangible (or tacit) assets. These intangible assets include organisational culture, human capital, knowledge, reputation, and skills (Itami, 1987; Lin, 2001). In order for a resource to be viewed as 'strategic' it must conform to three essential criteria. Firstly, strategic resources must be 'valuable' i.e. have the benefit to realise business opportunities; secondly, they must be 'rare', i.e. not readily available and difficult to acquire; thirdly and finally, they must be non-imitable and nonsubstitutable i.e. the resources can only be used for the specific relationship interaction (Barney, 1991; Das and Teng, 2000).

We seek to extend the RBV, combining it with social network theory. We focus on developing a framework for considering how this focus can allow organisations to integrate sustainability practices and eco-innovation processes into one value adding 'strategic' process.

\subsection{The knowledge-based view and network theory}

Essential to our argument is the flow of knowledge between organisations within a supply network. This may facilitate the development of new products and processes as well as the incremental improvement of existing ones. This builds on the work of Granovetter (1983) who introduced the idea of 'strong' and 'weak' ties within social network structures. He argued that knowledge flows are improved between individuals who are in 'acquaintance networks' (a large variety of weak ties) as opposed to individuals who are constrained within networks that have fewer but stronger relationships (strong ties). This notion is supported by the work of Connor and Prahalad (1996) and who postulated the knowledgebased view of the firm. These authors argue that a knowledgebased perspective can outweigh and mitigate opportunistic behaviours within supply networks. Dyer and Singh (1998) build on this work and examine the nature of the relationship as a unit of analysis. They argue that the relationship may facilitate the exchange of knowledge across organisational boundaries, identifying four sources of inter-organisational competitive advantage: relation-specific assets; knowledge-sharing routines; complementary resources/capabilities; and effective key sub-processes.

These elements support the 'dynamic capabilities' arguments postulated by Teece et al. (1997), allowing the inter-firm network to adapt to external environmental competitive and technological pressures. This seminal work was fundamental in laying the basis for understanding how an organisation can compete and adapt to external changes and shocks. A key external pressure on organisations has been the increasing importance of sustainability. This 
has essentially moved from a compliance-based process to a strategic issue facing virtually every type of organisation and interorganisational network. This led Hart (1995) to offer further development of RBV incorporating and defining sustainability as a strategic framework that should sit within the RBV. He defined this as the Natural Resource-Based View of the firm (NRBV) - he termed it as '.. a theory of competitive advantage based upon the firm's relationship to the natural environment'. He argued (Hart, 1995: 992) that there were essentially three types of natural (sustainable) capability: pollution prevention; product stewardship; and sustainable development. Pollution prevention focuses on issues such as packaging reduction, improved palletisation and logistics network optimisation, emission and effluent minimisation. Hart and Dowell (2011), in a review of Hart's original contribution, conclude that organisations tend to view this type of sustainable action as a 'cost saving' exercise and hence it has proved to be very popular. In Hart's original paper he describes pollution prevention as a case of continuous improvement that offers a low-cost competitive advantage. Product stewardship, which is defined as minimising the life-cycle costs appears to have been less appealing to organisations. This process may involve reengineering the product to make it more sustainable (e.g. BMW's attempts to produce a fully recyclable car.) In order to achieve these sorts of benefits organisations may have to manage their inter-organisational networks closely, requiring stakeholder integration. It may also involve pre-empting key competitors e.g. developing technologies that can give competitive advantage such as battery technology for electric cars. Sustainable Development or Clean Technology development as it was subsequently termed by Hart and Dowell (2011) is the final and most influential 'natural' strategic capability. This involves minimising the organisation's environmental growth and development and may include the adoption of 'reverse supply chains' (Kocabasoglu et al., 2007), requiring the incorporation of sustainability and environmental impact into every aspect of the supply network. This may involve a complete product redesign, or the design of completely new products and processes.

Unfortunately, as Hart and Dowell (2011: 1476) point out, the majority of organisations focus only on pollution prevention; they are not embedding sustainability into their long-run innovation cycles. They are also not seeing it as a major source of competitive advantage, rather as a compliance issue. This is perhaps because organisations view the sustainability agenda as 'in addition' to what they are already doing as opposed to it being embedded as part of 'what' they are actually doing. We now build on this argument by examining how supply networks can respond more effectively to these changes.

\subsubsection{Distinguishing between supply chains and networks}

The traditionally accepted view among practitioners and academics alike is that an organisation is part of a 'chain' or activity of supply, beginning from raw materials and finishing with the customer. A natural development from this perspective is the view that organisations operate within networks, some very complex others less so. The concept of a network is not new, indeed in 1939 Roethlisberger and Dickson's work argued about the importance of social networks within organisations. Since then the network concept has been progressively developed within management (see Nohria and Eccles, 1992). The use of network theory within supply chain has become increasingly common parlance, although this terminology is not without its issues. Harland (1996) outlined four main uses of the term 'supply chain management' (SCM): (1) the internal supply chain that integrates business functions involved in the flow of materials and information from the inbound to outbound ends of the business; (2) the management of dyadic or two party relationships with immediate suppliers; (3) the management of a chain of businesses including a supplier, a supplier's supplier, a customer's customer and so on and; (4) the management of a network of interconnected businesses involved in the ultimate provision of product and service packages required by end customers (Harland, 1996, p. S64). The authors argued that by using the network (and nodes within the network as focal points) as the unit of analysis, organisations are able to view themselves as part on an interrelated network. This in turn means there is a wider focus on relationship management, the understanding of ties, weak and strong, and the efficient management of knowledge flow within and between the networks.

Accordingly, networks may be seen as multi-dimensional, consisting of internal (inter-organisational) networks (Lincoln, 1982: 26) and external (intra-organisational) networks (DiMaggio and Powell, 1983: 148; Granovetter, 1983; Burt, 2000). An interorganisational network perspective seeks to understand how the various relationships between actors and nodes (ties) influence the network structure as a whole. Burt $(1980,79)$ provides a detailed schema for analysing network structures, recommending five different principles: cohesion; equivalence; prominence; range; and brokerage. Cohesion and equivalence are principles for sorting actors into common groups. Cohesion models group actors together if they share strong common relationships with one another; equivalence models group actors together if they have similar relations with other actors in the organisation (even though they may not be directly linked). Cohesion and equivalence models are both used to explain similarities in the attitudes and behaviours of the actors in an organisation. Prominence, range and brokerage models are used to explain the extent to which an actor is advantageously positioned relative to others in an organisation. Prominence models assess the popularity of actors in the network. Whereas range and brokerage models measure the extent to which actors can 'get away with' pursuing their own interests.

Using this concept of network theory, a supply network can be defined as the inter-organisational network of companies that exists upstream to any one company in the value system (Choi and Krause, 2006: 639). Supply networks are essentially an interconnected web of exchange relationships between the firm, its suppliers and its suppliers' suppliers. The structure of the supply network takes shape due to a constant exchange of valuable resources between these actors. As with any exchange network, supply networks can be viewed as complex adaptive systems with no single company deliberately orchestrating the totality of its design (Choi et al., 2001). The structure of a supply network forms over time through the constant interaction between a firm and its suppliers. The structure or pattern of relationships between the firm and its suppliers then influences the subsequent behaviour of each actor in the network. We use the industrial supply network as our research domain. The inter- and intra-organisational networks are responsible for information exchange. According to Burt (1980, 2004) the level and type of information exchanged will depend on the strength of the ties between actors. He argues that a network with a high degree of weak ties tends to facilitate a greater degree of information flow and thus new ideas than does a network with a few amounts of 'stronger' ties. Having established that 'networks' are an important and useful domain as a unit of analysis to understand the supply management process we now turn to discuss how innovation could be used as a catalyst to drive up levels of sustainability within a given network.

\subsubsection{Innovation as a key driver of sustainability}

Hart (1995) strongly argued that firms should view the development of 'clean technologies' as a source of long-run sustainable competitive advantage. Fifteen years later (Hart and Dowell, 2011), argued that firms had been reluctant to change. The reasons for this 
include how businesses cost such processes (Boons et al., 2013) or that the perceived strategic value is not recognised (Boons et al., 2013; Hart and Milstein, 2003; Hockerts and Morsing, 2008). Others (Carrillo-Hermosilla et al., 2010) have argued for ecoinnovation to be recognised by firms, defined as innovation that improves environmental performance'. This again aligns with the ideas of Hart (1995) when he discusses 'product stewardship' and 'clean technology development'.

The sustainability literature argues (see Klassen and Vachon, 2003; Vachon and Klassen, 2007) that firms continually need to improve their products and processes through constantly innovating, sometimes radically, but more commonly incrementally, in order to minimise harm to the environment and the communities in which they operate. Just as important is the need for firms to ensure that suppliers are doing likewise; we might term this an eco-innovation network. These eco-innovations may have the potential to change entire industries (Klewitz and Hansen, 2014).

The supply chain literature is beginning to focus on this important issue. Narasimhan and Narayanan (2013: 28) applied innovation to supply networks, stating that "innovation is the process of making changes to products, processes, and services that result in new value creation to the organisation and its customers by leveraging knowledge efforts of the firm and (or) that of its supply network partners". Innovation can be further divided into incremental or radical. Radical innovations embody a new technology that results in a new market infrastructure, while incremental innovations are products that provide new features, benefits, or improvements to the existing technology in the existing market (Garcia and Calantone, 2002). While these innovations may increase the economic performance of the firm, they may not necessarily lead to environmental and social benefits. This paper concentrates on building on the idea of eco-innovations. We present an idea that encompasses both the network supply side focus and product or process development. Eco-innovations are focused on the development of sustainable products and services for increased competitive advantage, an integrated sustainable innovation process that is defined by Hansen and Große-Dunker (2013, pp. 2407-2408) as “... [the] commercial introduction of a new or improved product, service, product-service system, or pure service which leads to environmental and (or) social benefits over the prior version's physical life-cycle".

Hart (1995; Hart and Dowell, 2011) proposes several sustainability strategies where innovation is a prominent component. One such strategy is pollution prevention that utilises technology focused on preventing harmful emissions at the front end of the process rather than relying on expensive 'end-of-pipe' pollution control devices. Similarly, clean technology strategies use innovations that reduce material and energy consumption through technological advancements that provide for human needs without straining the planet's resources (Hart, 1995; Hart and Dowell, 2011). Other scholars have reached similar conclusions about the importance of innovation in sustainability. For example, Klassen and Vereecke (2012) state that innovation is crucial in improving the management of social aspects of the supply chain. They stress the significance of obtaining social innovation capabilities which include the development of new markets and the identification of novel approaches to cost reduction by involving stakeholders from outside the established supply chain. Hockerts and Morsing (2008), argue that innovation plays a paramount role in the area of corporate sustainability. Boons et al. (2013) go so far as to say that eco-innovation can improve sustainability performance, where such performance includes ecological, economic, and social criteria. Having highlighted the importance of innovation in sustainability we now draw together the literature on supply networks, sustainability and innovation to propose a definition of eco-innovation supply networks as 'an interconnected web of suppliers within one industrial sector or between related industrial sectors that interact with a focal firm to develop sustainably focused innovations with the aim of improving economic, social, and environmental performance'.

\subsubsection{Gaps in existing sustainability frameworks}

By reviewing extant sustainability frameworks we show that innovation is highlighted as a key component of sustainability. We also demonstrate that scant attention has been paid to ways of finding such innovation. The Brundtland Commission provides a widely used definition of sustainable development, describing it as "development that meets the needs of the present without compromising the ability of future generations to meet their needs" (WCED, 1987, p. 8). Sustainable development integrates the consideration of economic growth, environmental protection, and social equity, simultaneously and on a macro-level (Figge and Hahn, 2004). When incorporated by the firm, it is sometimes called corporate sustainability (Figge and Hahn, 2004). These definitions stress the importance of the firm's ability to balance social, environmental, and economic factors, a concept known as the Triple Bottom Line (Elkington, 1998, 2004). A positive Triple Bottom Line reflects an increase in the company's value, including both its profitability and shareholder value and its social and environmental capital (Savitz and Weber, 2006).

One of the first sustainability frameworks in the supply chain literature was termed Sustainable Operations Management. Kleindorfer et al. (2005) outlined three factors contributing to the sustainability of a firm's operation: green product and process development; lean and green operations management and; remanufacturing and closed-loop supply chains. This framework includes a discussion of sustainable technologies and the importance of sustainable design in developing sustainable products. However, the authors stop there and do not explain how sustainable technologies might be found. Moreover, Sustainable Operations Management frameworks are, arguably, limited to the first two of Harland's (1999) SCM categories (internal operations and dyadic buyer-supplier relationships), due to the distinct focus on a firm's operations.

Linton et al. (2007) suggest the change of focus from operations management to SCM is important in sustainability because the supply chain considers the product from initial processing of raw materials to delivery to the customer. As an alternative framework to Sustainable Operations Management, Sarkis introduced the concept of 'green supply chain Management (GrSCM)' (Sarkis, 2003; Zhu and Sarkis, 2004; Rao and Holt, 2005). GrSCM is defined as "integrating environmental thinking into supply chain management, including product design, material sourcing and selection, manufacturing processes, delivery of the final product to the consumers, as well as end-of-life management of the product after its useful life" (Srivastava, 2007, pp. 54-55). The rubric of GrSCM includes concepts such as lifecycle analysis (Karna and Heiskanen, 1998; Rebitzer et al., 2004; Pennington et al., 2004), closed loop supply chains (Guide and Van Wassenhove, 2006, 2009), environmental technologies (Vachon and Klassen, 2007) and reverse logistics (Zhu and Sarkis, 2004). Many of these concepts include one or more type of product or process innovation. However, GrSCM frameworks provide little explanation on how to find sustainable technologies that may reside with suppliers. Furthermore, GrSCM frameworks concentrate on environmental issues to the exclusion of societal concern.

Several frameworks for Sustainable Supply Chain Management (SSCM) have been advanced. Seuring and Muller's (2008) SSCM framework includes: triggers for SSCM including stakeholder pressures; supplier management for risks and performance and; SCM for sustainable products which considers the product's entire 
life-cycle. Carter and Rogers (2008) focus instead on strategy, organisational culture, transparency, and risk management. The role of innovation in supply chain sustainability is given limited attention within these two frameworks. The Pagell and Wu (2009) SSCM framework does, however, acknowledge the importance of innovation. They used case studies of ten exemplar companies and found that an organisational capability to innovate is precursor for successful SSCM. Yet, while they acknowledge innovation's importance, their framework does not suggest how to find this innovation. In addition, it can be argued that GrSCM and SSCM frameworks only cover the first three of Harland's (1999) categories (internal operations, dyadic, and chain) and do not move into the fourth category of networks.

Miemczyk et al. (2012) state that sustainability needs to be understood from an even higher level of analysis than the supply chain: the network level. Roome (2001) explains "networks have an identified role in innovation for environmental management and sustainable development" (p. 70). However, studies examining sustainability at the network level are rare (Miemczyk et al., 2012). One framework, van Bommel (2011), does move into Harland's (1999) fourth category of networks. He argues that the capability to develop a sustainability strategy is influenced by the innovation power of the focal company and its supply network. He proposes that focal companies will choose a defensive (risk-based) strategy when the innovation characteristics and management approaches represent a low level of innovation power and an offensive strategy (development of sustainable products) when a high level of innovation power is present (van Bommel, 2011). While the van Bommel (2011) framework sees innovation as a key criterion in determining sustainability strategies, it does not explain how firms can find innovations within industrial supply networks. We attempt to fill this gap by outlining three network typologies for developing eco-innovations.

\section{Towards a conceptual framework for sustainable supply networks}

We now move towards developing a conceptual framework for eco-innovation supply networks (see Table 1 ). We advance a typology of three supply network designs suited to building ecoinnovations. We use the SCM and network literatures to highlight contrasting suggestions for finding innovations that may reside with suppliers. We argue that firms can access innovation by developing strong ties with strategic suppliers in order to benefit from the knowledge and technology that may spill-over from supplier to buyer during the NPD process; we term these 'tight' networks. We propose that this network structure is more likely to

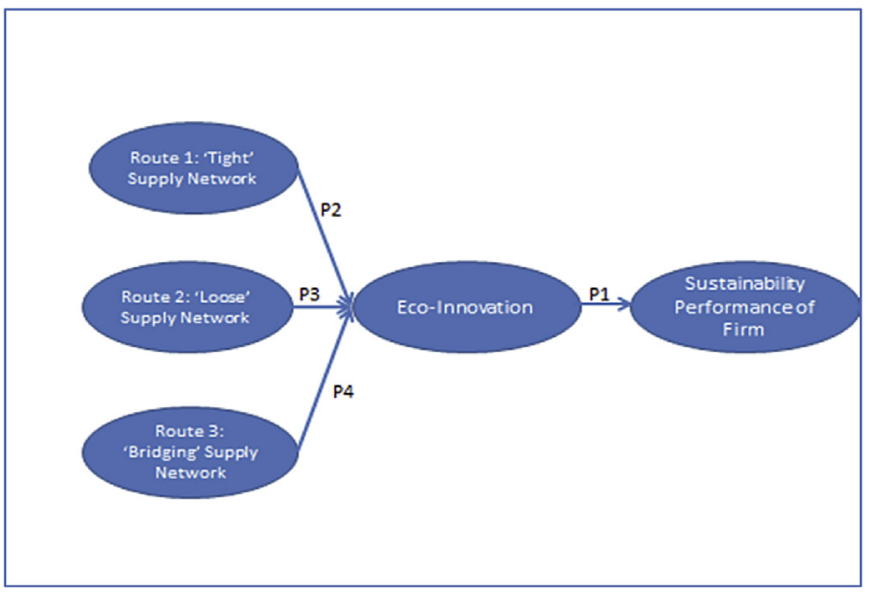

Fig. 1. Relationship between propositions.

lead to the development of incremental eco-innovations. Our second typology is 'loose' networks; these involve creating multiple weak ties to non-strategic suppliers in order to increase the opportunities for finding innovations. This is a form of environmental scanning. Our final typology we call a 'bridging' network, where we suggest that firms gain access to innovations by building weak ties to suppliers that bridge structural holes in the network. We suggest that employing these last two typologies is more likely to lead to the discovery of radical eco-innovations leading to the development of innovative clean technologies. Fig. 1 depicts the interrelationship between the four propositions and our network typologies.

\subsection{Eco-innovation and its effect on sustainability performance}

The media, governments, NGOs and consumers make little distinction between whether a firm or its suppliers cause harm to the environment or society (Sharma and Henriques, 2005; but see the Dodds-Frank Act, 2010/2013). Therefore, when the firm attempts to improve sustainability performance, suppliers need to be closely involved in the process. It follows that discovering and developing eco-innovations and then transferring them to other suppliers to allow for implementation within their operations may be one way to enhance a firm's sustainability performance in the eyes of external stakeholders.

Corporate sustainability performance (CSP) is a measure of the extent to which a firm embraces economic, environmental, social, and governance factors into its operations, and ultimately the

Table 1

Eco-innovation supply network typology.

\begin{tabular}{|c|c|c|c|c|}
\hline Supply network strategy & Description & Resourcing & Eco-innovation focus & Potential eco-innovation outcomes \\
\hline Tight (strong ties) & $\begin{array}{l}\text { Developing new products with } \\
\text { existing major collaborators. Focus } \\
\text { on working with key supplier } \\
\text { partners }\end{array}$ & $\begin{array}{l}\text { Focused strategic resource. } \\
\text { Cross-functional teams working } \\
\text { closely with supplier teams. }\end{array}$ & Process/product & $\begin{array}{l}\text { Incremental eco-innovations. High } \\
\text { level of organisational innovations. }\end{array}$ \\
\hline Loose (weak ties) & $\begin{array}{l}\text { Scanning the supply network to } \\
\text { acquire new eco-innovations. }\end{array}$ & $\begin{array}{l}\text { High degrees of supply market } \\
\text { intelligence required. }\end{array}$ & Product/process & $\begin{array}{l}\text { Radical eco-innovations, low } \\
\text { organisational eco-innovations due } \\
\text { to lack of visibility. Focus on eco- } \\
\text { centricity i.e. working with eco- } \\
\text { focused suppliers }\end{array}$ \\
\hline Bridging (weak ties) & $\begin{array}{l}\text { Developing new and novel eco- } \\
\text { innovations. } \\
\text { Use of Open Innovation and black } \\
\text { box techniques }\end{array}$ & $\begin{array}{l}\text { High degrees of supply market } \\
\text { intelligence required. }\end{array}$ & Product/process & $\begin{array}{l}\text { Radical eco-innovations, low } \\
\text { organisational eco-innovations due } \\
\text { to lack of visibility. Focus on eco- } \\
\text { centricity i.e. working with eco- } \\
\text { focused suppliers }\end{array}$ \\
\hline
\end{tabular}


impact these factors have on the firm and society (Artiach et al., 2010). Awaysheh and Klassen (2010) extended the CSP concept into the supply chain, stating that sustainable supply chain performance is concerned with company level engagement, capturing the extent to which the focal firm actively engages in sustainable supply chain practices and its commitment to these activities in the supply chain. These practices may improve a firm's sustainability performance. They include investment in clean technologies for manufacturing that reduce harmful emissions and designing products that use fewer resources and raw materials (Hervani et al., 2005; Grosvold et al., 2014).

A firm can engage in these practices by taking newly discovered eco-innovations and transferring them to suppliers so that the technology or process can be implemented in that supplier's operations. For example, process eco-innovations usually incorporate cleaner production technologies that reduce waste and effluents during raw material extraction, manufacturing and distribution; three activities often within a suppliers remit (Huber, 2008; Rennings et al., 2006). Product eco-innovations engage suppliers in the design stage potentially leading to the use of more environmentally sound (Lamming et al., 1999) materials and reductions in product and packaging waste (Hart and Milstein, 2003; van Hemel and Cramer, 2002). Implementing organisational ecoinnovations in a supplier's operations can lead to an improvement in the welfare of the supplier's workforce (Klewitz and Hansen, 2014). As external stakeholders take a more holistic view of sustainability they will tend to see a firm's CSP improving as suppliers minimise the environmental and social impact of their operations. Therefore, we suggest that once an eco-innovation is identified the focal firm should aim to transfer these technologies and processes to other suppliers so they can be implemented in supplier operations. This leads to our first proposition:

P1: Firms that implement eco-innovations in a supplier's operation are more likely to improve sustainability performance than firms that do not.

\subsection{Building strong ties with strategic suppliers}

Determining how firms access eco-innovations in supply networks requires an understanding of what motivates a firm to look beyond its boundaries for innovation. We draw on the Extended Resource Based View (ERBV) discussed earlier to explain why firms enter into supplier relationships and how these relationships create access to strategically important resources. Several authors suggest that the RBV is limited to a discussion of resources and capabilities existing internally within the firm and fails to acknowledge strategic resources that may be present externally (McEvily and Zaheer, 1999; Afuah, 2000; Das and Teng, 2000). The ERBV is founded on the assumption that strategic resources beyond the boundaries of the firm can be accessed, especially given the existence of certain types of inter-firm relationships (Lewis et al., 2010). Competitiveness depends not only on individual resources and capabilities held by the firm, but also on those shared with suppliers or clusters of firms (Wilk and Fensterseifer, 2003). Lewis (2000) notes that if the resources provided cannot be copied or replaced by competitors, their ownership is not of critical importance, and that many strategic resources developed in manufacturing processes are in fact owned by suppliers. Strategic resources can include assets, capabilities, organisational processes, firm attributes, information, and knowledge (Lewis et al., 2010).

It becomes clear that a firm can access strategic resources through relationships and ties with suppliers. Theses ties permit the exchange of valuable knowledge and technology. The strength of a tie is a combination of the amount of time, the emotional intensity, the intimacy (mutual confiding), and the reciprocal services that characterise the tie (Granovetter, 1973). Acquaintances (weak ties) are less likely to be socially involved with one another than are our close friends (strong ties) (Granovetter, 1973, 1983). Applying this concept to industrial supply networks, we see that a firm has strong ties to the suppliers with which it interacts closely and on a regular basis. These suppliers are often strategically important to the firm. The firm has weak ties with those suppliers with which it engages infrequently, usually in a non-strategic capacity.

The SCM literature suggests that the creation of strong ties between a firm and a small number of strategic suppliers may lead to knowledge and technology spill-overs from the supplier to the firm during the NPD process (Mayer, 2006; Koufteros et al., 2007; Perols et al., 2013). The acquisition and transfer of knowledge between buyers and suppliers represents a fundamental driver of innovation, enabling parties to coordinate and discover new solutions to technical and commercial challenges that exist in the market (Cousins et al., 2011). Perols et al. (2013) propose that 'supplier integration' has a positive technology spill-over affect, providing buyers with knowledge of external technology innovations and the opportunity to appropriate these innovations. Some authors go so far as to argue that tempting suppliers into an NPD project requires a 'rationalisation' of the supply base (e.g., Shin et al., 2000). Following rationalisation, Shin et al. (2000) suggest that the few remaining suppliers become highly integrated into the firm's products or processes. The underlying assumption is that such integration provides returns in the form of higher product innovation levels resulting from knowledge and technology spill-overs that occur during the process (Mayer, 2006; Koufteros et al., 2007).

While this literature focuses on the broad notion of 'innovation,' the principal of building strong ties to strategic suppliers can easily be extended to eco-innovations. The only difference here is that the objective is not merely profit maximisation but the development innovations that minimise harm to the environment and society. Strong ties are needed to transfer complex knowledge, implement ideas, and exploit them via technology refinement and product development (Michelfelder and Kratzer, 2013). Strong ties have been shown to lead to higher reciprocity in inter-organisational alliances (Uzzi, 1997) and to have a positive relationship with knowledge transfer (Kale and Singh, 2007). Simard and West (2006) state that strong ties are characterised by redundant information overlapping with the existing knowledge base of the companies involved and these ties are associated with the exploitation of existing technologies. This indicates that strong ties tend to lead to incremental innovations (West, 2006). So, while strong ties can lead to the development of eco-innovations, these innovations are more likely to be incremental improvements on existing technologies or processes. Incremental innovations can include the use of clean technologies during manufacturing to reduce carbon emissions or focussing on process improvements that enhance worker welfare such as addressing excessive overtime. This leads to our second proposition:

P2: Firms that build strong ties to strategic suppliers will have a higher propensity to develop incremental eco-innovations than firms that do not.

The idea of strong ties between the firm and its strategic suppliers is depicted in Fig. 2 below.

Interestingly, the network literature suggests quite a different route for finding innovations. In the next section, we use network theory and the network literature to explore the nature of industrial supply networks and advance two alternative routes to discovering eco-innovations. 


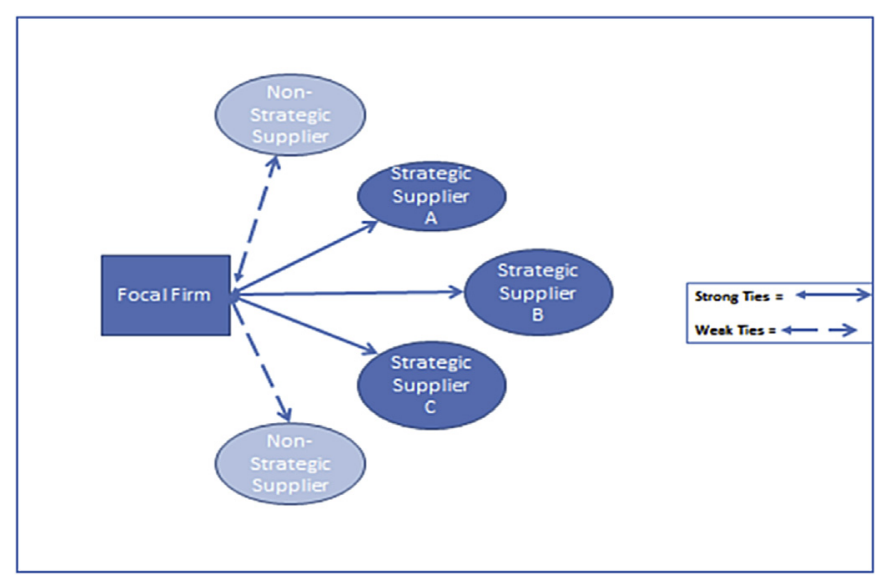

Fig. 2. 'Tight' supply networks: building strong ties to strategic suppliers.

\subsection{Creating multiple weak ties with suppliers}

In general, the network literature indicates that a firm should not limit its relationships to a handful of strategic partners but instead create multiple weak ties to enhance its opportunities for finding innovations. Granovetter (1973) maintains that while strong ties foster efficient interactions, weak ties serve as bridges to more novel, unique, or timely information. While densely clustered strong-tie groups execute efficiently and effectively via the free and routine sharing of information, information homogeneity is known to develop in strong-tie clusters, leading to long-term unchallenged group consensus (Harrison and Carroll, 2002; Wenger, 1998). Actors embedded solely in strong-tie groups actually constrain their own performance, due to the self-inflicted bounded rationality of group members. Conversely, actors cultivating weak-tie connections gain access to more unique 'outside' perspectives and information, and are thus better positioned for innovation than their strong-tie group counterparts (Granovetter, 1973).

Innovation is an information intensive activity in terms of both information collection and information processing (Ahuja, 2000; Lawson et al., 2009). Each additional actor to which a firm has access serves as an information-processing mechanism, absorbing, sifting, and classifying new technical developments and going well beyond the information-processing capabilities of a single firm (Ahuja, 2000; Lawson et al., 2009). Firms on their own can only pursue a finite number of technologies and lines of research; however, through collaboration, firms can achieve economies of specialisation (Koufteros et al., 2007). As network actors continue to specialise and impart this knowledge and expertise to other actors, the potential for generating innovations grows exponentially (Koufteros et al., 2007). Fox et al. (2013) found that organisations connected to many partners may be expected to be more innovative than those connected to fewer. Shan et al. (1994) established that the number of collaborative relationships a firm creates is positively related to its innovation output. In a study of the chemical industry, Ahuja (2000) found that the greater the number of weak ties possessed, the greater the subsequent innovation output of the firm. He explained that a firm's weak ties serve as a mechanism for knowledge spill-overs and contribute positively and significantly to its innovation output (Ahuja, 2000). Fig. 3 depicts the focal firm creating weak ties to supplier A1, A2, B1, C1.

Weak ties can give a company access to non-redundant information and offer the firm an opportunity to explore new technologies (Simard and West, 2006; Ahuja, 2000). Unlike those associated with strong ties, this new technology can take the form

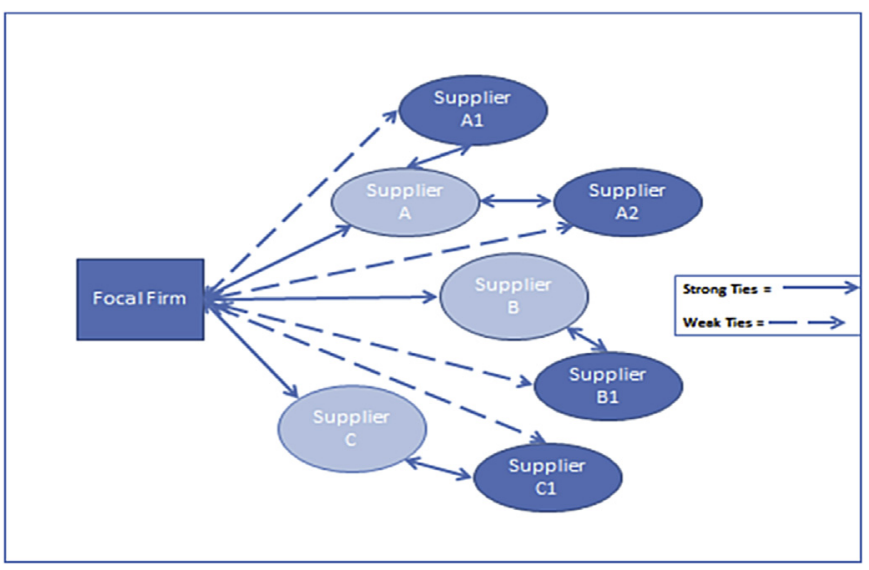

Fig. 3. "Loose" supply networks: building weak ties to multiple suppliers.

of radical innovation. Radical innovations are major departures from, or discontinuities in, the state of current knowledge in terms of product performance, process technology, or substantial costsaving technology; thus, they embody high degrees of new knowledge (Utterback and Abernathy, 1975; Liefer et al., 2000; Song and Di Benedetto, 2008). These innovations can be classed as eco-innovations if they provide environmental or social benefits. Radical eco-innovations have the ability to change entire industries through dramatic changes to products, as seen with recent developments in electric vehicles, or through significant process innovations such as sourcing from home markets to reduce carbon emissions and gain more control over labour conditions (e.g. American Apparel in the US, or Manomama in Germany) (Plieth et al., 2012; Porter and Kramer, 2011; Hansen and Große-Dunker, 2013).

Johnsen (2011) believes that it is insufficient to focus purely on the involvement of suppliers connected directly to the firm when seeking radical innovations. He concludes that when companies face conditions of technological uncertainty, managers need to involve the wider supply network rather than just the suppliers they deal with directly (Johnsen, 2011). Such conditions may require connecting with new suppliers outside existing networks, those that are not within the company's usual field of vision (Birkinshaw et al., 2007; Ragatz et al., 2002; Song and Di Benedetto, 2008; Johnsen, 2011). Therefore, we posit that weak ties provide access to new knowledge and technologies, thus providing a greater opportunity for discovering radical eco-innovations. This leads to the third proposition:

P3: Firms that create multiple weak ties to suppliers will have a higher propensity to discover radical eco-innovations than firms that do not.

We now turn our attention to the concept of structural holes and suggest ways to access the novel ideas and technologies likely to be possessed by suppliers that bridge these holes in industrial supply networks.

\subsection{Developing weak ties to suppliers that bridge structural holes}

Suppliers that have exclusive access to other densely knit clusters of suppliers, or who span industry boundaries, have the potential to possess novel, transferable ideas and technologies. When two densely knit clumps of strong ties are not connected to each other, a structural hole is present in the network (Burt, 2004). Burt (2004) suggests that people who are situated near holes in a social 
structure are more likely to have good ideas because people's opinions and behaviours are more homogeneous within groups than between groups. Therefore, people connected across groups are more familiar with alternative ways of thinking and behaving, providing more options from which to select and synthesise (Burt, 2004). These structural holes are bridged by the creation of weak ties (Granovetter, 1983; Burt, 2004). A bridging tie links two nodes whose respective contacts are not otherwise linked and is by definition always a weak tie (Michelfelder and Kratzer, 2013). Companies that bridge structural holes in the network occupy powerful brokerage positions as they arbitrate the information flows between densely knit clumps of strong ties (Kogut, 2000).

Applying these concepts to industrial supply networks, we see that suppliers who bridge densely knit clumps of strong ties either within the same industry or across different industries span a structural hole in the network, permitting access to new ideas and technologies. Based on occasional rather than frequent interactions, these ties offer more pathways to new information because they provide access to different networks and thus different sources of information (Granovetter, 1985). Take, for example, an aerospace supplier who forms a bridging weak tie to a supplier in the automotive industry. By sharing knowledge or technology not previously encountered in each other's industry, both parties benefit from new ideas and innovations. If this exchange leads to an improvement in environmentally or socially responsible workplace practices, then eco-innovations may result. The focal firm can then access these innovations by building weak ties to these suppliers. Fig. 4 shows the focal firm creating weak ties with suppliers A2 and $B 1$ as these suppliers bridge the structural holes to suppliers $Z$ and Y, respectively. Suppliers Z and Y can either reside within the same industry (but in a distinct supply network) or in different industries.

We suggest that firms should concentrate on building ties with suppliers that bridge structural holes, as these relationships are more likely to lead to the discovery of radical eco-innovations. A structural hole indicates that people on either side of the hole have access to different flows of information (Hargadon and Sutton, 1997). Acting as a bridge between such diverse actors may enable a company to tap into the knowledge contained in multiple networks (McEvily and Zaheer, 1999). Bridging ties may foster greater information access than strong ties due to 'transitivity.' This is the principle of acquiring resources not only from the direct weak-tie connection, but from any other direct connections held by the weak tie partner (Rapoport and Horvath, 1961; Autry and Griffis, 2008). A firm seeking to bridge weak ties has the capability to tap into the resource base of an entirely different network via a single contact (Vanhaverbeke, 2006). Therefore, firms that create weak ties to suppliers that bridge structural holes may benefit from new knowledge and technologies, creating a greater likelihood of uncovering radical innovations. If these innovations address environmental or social issues, they can be classed as radical ecoinnovations. This leads to our fourth proposition:

P4: Firms that create weak ties to suppliers that bridge structural holes in industrial supply networks will have a higher propensity to discover radical eco-innovations than firms that do not.

Table 1 provides a summary of the eco-innovation supply network typology. Here we see that a "tight" supply network strategy requires focused strategic resources that are acquired by cross-functional teams in the focal firm working closely with suppliers. In the "loose" supply network configuration the focal firm scans the supply network to acquire eco-innovations by building weak ties to new supplies. In the third configuration, the focal firm builds relationships with eco-focused suppliers (i.e. eco-centricity) who bridge structural holes between existing and new industrial networks.

\section{Conclusion}

According to Miemczyk et al. (2012), the majority of papers on sustainability in the SCM literature use an internal/functional or dyadic level of analysis and studies examining sustainability at the network level are rare. Using a network perspective, this paper has advanced a conceptual framework for Sustainable Supply Networks. By reviewing existing sustainability frameworks we have highlighted the importance of innovation in sustainability. We have then outlined three routes for finding eco-innovations in industrial supply networks. We suggest that once an eco-innovation is discovered, the technology or process should be transferred to other supplies in the network to improve the sustainability performance of the firm in the eyes of external stakeholders.

We recommend that researchers attempting to test the above propositions use a single or multiple case study design. To test the

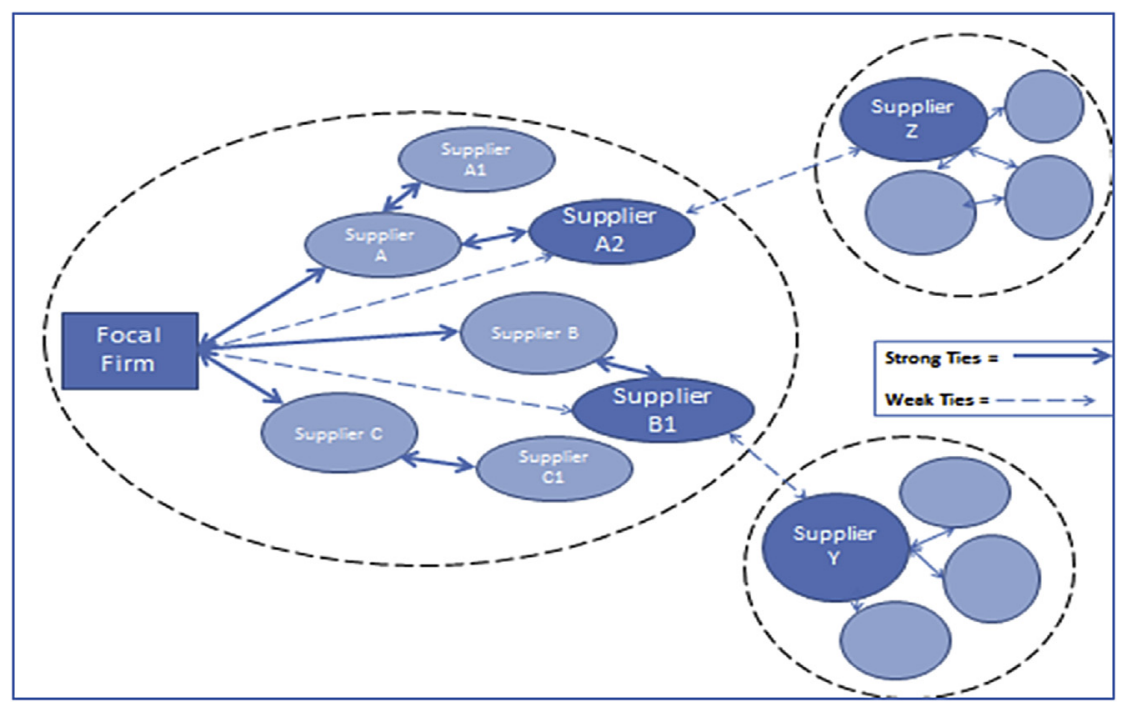

Fig. 4. "Bridging" supply networks: building weak ties to suppliers that bridge structural holes. 
first proposition, researchers should establish a firm's current sustainability performance level and then possibly use a longitudinal study to investigate whether or not the implementation of eco-innovations in a supplier's operation leads to demonstrable sustainability improvements. To test the second proposition, researchers could study the NPD process between a firm and two or three strategic suppliers to determine if knowledge or technology spill-over is more significant and whether incremental ecoinnovations result. For the third proposition, researchers would need to study suppliers connected to the firm by weak ties. Interesting findings would include whether (and how) weak ties might lead to the development of eco-innovations and whether these are incremental or radical. To test the fourth proposition, researchers should first establish where structural holes exist in the network, possibly using Social Network Analysis, and then determine if building weak ties to these suppliers leads to radical innovations.

\subsection{Research limitations and areas for future research}

One limitation of this paper is that the propositions are based on the literature and have not been empirically tested. Campbell (1974) explains that the transition from framework to formal theory occurs as "frameworks are tested against reality until they are eventually developed into theories as research study builds upon research study" (p. 415). Our hope is that this paper will stimulate additional theory building and conceptual development within the supply chain management discipline. Given the early development of the framework, the propositions should be considered preliminary and should be subjected to further refinement through a variety of empirical research methods.

A second limitation is the distinct focus on suppliers to the exclusion of other stakeholders. We view suppliers as being critical stakeholders in firm sustainability as they directly affect the product or service provided by the firm. However, we do acknowledge the importance of considering other stakeholders when addressing sustainability. Roome (2001), states that stakeholder analysis is significant for sustainability because it highlights the importance of frequent, meaningful interactions between companies and stakeholders. Therefore, an important future area of study is the role other stakeholders (such as community actors, governments, non-governmental organisations, and employees) play in Sustainable Supply Networks. The use of Stakeholder Theory to investigate how stakeholders influence the economic, environmental, and social activities of industrial supply networks could prove particularly intriguing.

\subsection{Research and managerial implications}

We believe that the framework advanced here should prove interesting to academics because it begins to fill a gap in existing sustainability framework theories. We have highlighted that innovation is a key driver of sustainability and that existing frameworks do not explain how to find eco-innovations that may reside with suppliers. We have attempted to fill this gap by providing three network structures to finding eco-innovations. Furthermore, we have explored a contradiction between the SCM and network literature and have suggested that both strong ties with strategic suppliers and weak ties with multiple suppliers can lead to the discovery of eco-innovations. The framework provides academics with propositions that can be tested in future empirical research.

We hope that this paper will be of interest to managers because it highlights the importance of looking beyond firm boundaries for eco-innovations. Further, we suggest to managers that once these eco-innovations are discovered, they should be transferred to other suppliers and then implemented to improve sustainability performance. In addition, we provide managers with three alternative network structures for finding eco-innovations. Finally, we propose to managers that strong ties are more likely to lead to incremental innovation improvements while weak ties, and particularly weak ties to suppliers bridging structural holes, are more likely to lead to radical innovations. Managers are provided with the opportunity to explore each alternative route as part of their sustainability strategy.

\section{References}

Afuah, A., 2000. How much do your co-opetitors' capabilities matter in the face of technological change? Strateg. Manag. J. 21 (3), 387-404.

Ahuja, G., 2000. Collaboration networks, structural holes, and innovation: a longitudinal study. Adm. Sci. Q. 45, 425-455.

Arya, B., Lin, Z., 2007. Understanding collaboration outcomes from an extended resource-based view perspective: the roles of organizational characteristics, partner attributes, and network structures. J. Manag. 33 (5), 697-723.

Artiach, T., Lee, D., Nelson, D., Walker, J., 2010. The determinants of corporate sustainability performance. Account. Finance 50, 31-51.

Autry, C.W., Griffis, S.E., 2008. Supply chain capital: the impact of structural and relational linkages on firm execution and innovation. J. Bus. Logist. 29 (1).

Awaysheh, A., Klassen, R.D., 2010. The impact of supply chain structure on the use of supplier socially responsible practices. Int. J. Oper. Prod. Manag. 30 (12), 1246-1268.

Barney, J.B., 1991. Firm resources and sustained competitive advantage. J. Manag. 17 (1), 99-120.

Barney, J.B., 2001. Resource-based theories of competitive advantage: a ten-year retrospective on the resource-based view. J. Manag. 27, 643-650.

Benkler, Y., 2006. The Wealth of Networks; How Social Production Transforms Markets and Freedom. Yale University Press, New Haven and London.

Birkinshaw, J., Bessant, J., Delbridge, R., 2007. Finding, forming, and performing: creating networks for discontinuous innovation. Calif. Manag. Rev. 49, 67-83.

Boons, F., Montalvo, C., Quist, J., Wagner, M., 2013. Sustainable innovation, business models and economic performance: an overview. J. Clean. Prod. 45, 1-8.

Burt, R.S., 1980. Models of network structure. Annu. Rev. Sociol. 6, 79-141.

Burt, R.S., 1992. Structural Holes. Harvard University Press, Cambridge, Mass.

Burt, R.S., 1995. Structural Holes: the Social Structure of Competition. Harvard University Press, Cambridge, Mass.

Burt, R.S., 2000. The network structure of social capital. In: Sutton, Robert I., Staw, Barry M. (Eds.), Research in Organizational Behavior. JAI Press, Greenwich, Conn., pp. 345-423

Burt, R.S., 2004. Structural holes and good ideas. Am. J. Sociol. 110, 349-399.

Carrillo-Hermosilla, J., del Rio, P., Konnola, T., 2010. Diversity of eco-innovations: reflections from selected case studies. J. Clean. Prod. 18 (10-11), 1073-1083.

Campbell, D.T., 1974. Evolutionary epistemology. In: Schilpp, P.A. (Ed.), The Philosophy of Karl Popper, vol. 14. Open Court, LaSalle, IL, pp. 413-463.

Carter, C.R., Rogers, D.S., 2008. A framework of sustainable supply chain management: moving toward new theory. Int. J. Phys. Distrib. Logist. Manag. 38 (5), $360-387$.

Chesbrough, H., 2004. Managing open innovation. Res. Technol. Manag. 47 (1) 23-26.

Chesbrough, H., VanHaverbeke, W., West, J., 2006. Open Innovation: Researching a New Paradigm. Oxford University Press, Oxford.

Choi, T.Y., Dooley, K., Rungtusanatham, M., 2001. Supply networks and complex adaptive systems: control versus emergence. J. Oper. Manag. 19, 351-366.

Choi, T.Y., Krause, D.R., 2006. The supply base and its complexity: implications for transaction costs, risks, responsiveness, and innovation. J. Oper. Manag. 24 (5) 637-652.

Connor, K.R., Prahalad, C.K., 1996. A resource-based theory of the firm: knowledge versus opportunism. Organ. Sci. 7, 477-501.

Cousins, P.D., 2005. The alignment of appropriate firm and supply strategies for competitive advantage. Int. J. Oper. Prod. Manag. 25 (5), 403-428.

Cousins, P., Lamming, R., Bowen, F., 2004. The role of risk in environment-related supplier initiatives. Int. J. Oper. Prod. Manag. 24 (6), 554-565.

Cousins, P.D., Lawson, B., Petersen, K.J., Handfield, R.B., 2011. Breakthrough scanning, supplier knowledge exchange, and new product development performance. J. Prod. Innov. Manag. 28, 930-942.

Das, T.K., Teng, B.S., 2000. A resource-based theory of strategic alliances. J. Manag 26 (1), 31-61.

DiMaggio, P.J., Powell, W.W., 1983. The iron cage revisited: institutional isomorphism and collective rationality in organizational fields. Am. Sociol. Assoc. 48 (2), 147-160.

Dodd-Frank Act Section 1502, 2013. The Dodd-Frank Wall Street Reform and Consumer Protection Act originally published 2010, updated section 1502 published 2013.

Dyer, J.H., Singh, H., 1998. The relational view: cooperative strategy and source of interorganizational competitive advantage. Acad. Manag. Rev. 23 (4), 660-679.

Elkington, J., 1998. Cannibals with Forks: the Triple Bottom Line of the 21st Century. New Society Publishers, Stony Creek, CT. 
Elkington, J., 2004. Enter the triple bottom line. In: Henriques, A., Richardson, J. (Eds.), The Triple Bottom Line: Does It All Add Up? Earthscan, London, pp. $1-16$.

Frohlich, M.T., Westbrook, R., 2001. Arcs of integration: an international study of supply chain strategies. J. Oper. Manag. 19, 185-200.

Figge, F., Hahn, T., 2004. Value-oriented impact assessment: the economics of a new approach to impact assessment. J. Environ. Plan. Manag. 47 (6), 921-941.

Fox, G.L., Smith, J.S., Cronin, J.J., Brusco, M., 2013. Weaving webs of innovation. Int. J. Oper. Prod. Manag. 33, 5-24.

Garcia, R., Calantone, R., 2002. A critical look at technological innovation typology and innovativeness terminology: a literature review. J. Prod. Innov. Manag. 19 110-132.

Granovetter, M.S. 1973. The strength of weak ties. Am. J. Sociol. 78, 1360-1380.

Granovetter, M.S., 1983. The strength of weak ties: a network theory revisited. Sociol. Theory $1,201-233$.

Granovetter, M., 1985. Economic-action and social-structure-the problem of embeddedness. Am. J. Sociol. 91 (3), 481-510.

Grosvold, J., Hoejmose, S., Roehrich, J., 2014. Squaring the circle: management, measurement and performance of sustainability in supply chains. Supply Chain Manag. Int. J. 19 (3).

Guide, V.D.R., Van Wassenhove, L.,N., 2006. Feature issue on closed-loop supply chains. Prod. Oper. Manag. 15 (3-4).

Guide, V.D.R., Van Wassenhove, L.N., 2009. The evolution of closed-loop supply chain research. Oper. Res. 57 (1), 10-18.

Gulati, R., 1995. Social structure and alliance formation pattern: a longitudinal analysis. Adm. Sci. Q. 40, 619-642.

Gulati, R. 1999. Network location and learning: the influence of network resources and firm capabilities on alliance formation. Strateg. Manag. J. 20 (5), 397-420.

Håkansson, Håkan, Snehota, Ivan, 1995. Developing Relationships in Business Networks. Routledge, London and New York.

Hargadon, A., Sutton, R.I., 1997. Technology brokering and innovation in a product development firm. Adm. Sci. Q. 42, 716-749.

Harland, C.M., 1996. Supply chain management: relationships, chains and networks, $\mathrm{Br}$. J. Manag. 7, S63-S80 (special issue).

Handfield, R., Lawson, B., 2007. Integrating suppliers into new product development. Res.-Technol. Manag. 50 (5), 44-51.

Handfield, R., Petersen, K., Cousins, P., Lawson, B., 2009. An organizational entrepreneurship model of supply management integration and performance outcomes. Int. J. Oper. Prod. Manag. 29 (2), 100-126.

Hansen, E.G., Große-Dunker, F., 2013. Sustainability-oriented innovation. In: Idowu, S.O., Capaldi, N., Zu, L., Das Gupta, A. (Eds.), Encyclopedia of Corporate Social Responsibility, vol. 4. Springer, Heidelberg, Germany: New York, pp. 2407-2417.

Harrison, R.J., Carroll, G.R., 2002. The dynamics of cultural influence networks Comput. Math. Organ. Theory 8 (1), 5-30.

Hart, S., Milstein, M., 2003. Creating sustainable value. Acad. Manag. Exec. 17, 56-67.

Hart, S.L., 1995. A natural-resource-based view of the firm. Acad. Manag. Rev. 20 (4), 986-1014.

Hart, S.L., Dowell, G., 2011. The natural resource based view of the firm - fifteen years after. J. Manag. 37, 1464-1479.

Hervani, A.A., Helms, M.M., Sarkis, J., 2005. Performance measurement for green supply chain management. Benchmarking Int. J. 12 (4), 330-353.

Hendricks, K.B., Singhal, V.R., 2003. The effect of supply chain glitches on shareholder wealth. J. Oper. Manag. 21 (5), 501-522.

Hockerts, K., Morsing, M., 2008. A Literature Review on Corporate Social Responsibility in the Innovation Process, pp. 1-36.

Huber, J., 2008. Technological environmental innovations (TEIs) in a chain analytical and life-cycle-analytical perspective. J. Clean. Prod. 16, 1980-1986.

Itami, H., 1987. Mobilizing Invisible Assets. Harvard University Press, Cambridge Mass.

Johnsen, T.E., 2011. Supply network delegation and intervention strategies during supplier involvement in new product development. Int. J. Oper. Prod. Manag. 31, $686-708$.

Jones, C., Hesterly, W.S., Borgatti, S.P., 1997. A general theory of network governance: exchange conditions and social mechanisms. Acad. Manag. Rev. 22 (4), $911-945$.

Kale, P., Singh, H., 2007. Building firm capabilities through learning: the role of the alliance learning process in alliance capability and firm-level alliance success. Strateg. Manag. J. 28 (10), 981-1000.

Karna, A., Heiskanen, E., 1998. The challenge of 'product chain' thinking for product development and design: the example of electrical and electronics products. J. Sustain. Prod. Des. 4 (1), 26-36.

Klassen, R.D., Vachon, S., 2003. Collaboration and evaluation in the supply chain: their impact on plant-level environmental investment. Prod. Oper. Manag. 12 (3), 336-352.

Klassen, R.D., Vereecke, A., 2012. Social issues in supply chains: capabilities link responsibility, risk (opportunity), and performance. Int. J. Prod. Econ. 140 103-115.

Klein, N., 2014. This Changes Everything: Capitalism versus the Climate. Simon \& Schuster, New York, New York.

Kleindorfer, P.R., Singhal, K., Van Wassenhove, L.N., 2005. Sustainable operations management. Prod. Oper. Manag. 14, 482-492.

Klewitz, J., Hansen, G., 2014. Sustainability-oriented innovation of SMEs: a systematic review. J. Clean. Prod. 65, 57-75.
Kocabasoglu, C., Prahinski, C., Klassen, R., 2007. Linking forward and reverse supply chain investments: the role of business uncertainty. J. Oper. Manag. 25, $1141-1160$.

Kogut, B., 2000. The network as knowledge: generative rules and the emergence of structure. Strateg. Manag. J. 21, 405-425.

Koplin, J., Seuring, S., Mesterharm, M., 2007. Incorporating sustainability into supply policies and supply processes in the automotive industry: the case of Volkswagen. J. Clean. Prod. 15 (11), 1053-1062.

Koufteros, X.A., Cheng, E., Lai, K.H., 2007. Black-box and gray-box supplier integration in product development: antecedents, consequences and the moderating role of firm size. J. Oper. Manag. 25, 847-870.

Krause, D.R., Vachon, S., Klassen, R.D., 2009. Special topic forum on sustainable supply chain management: introduction and reflections on the role of purchasing management. J. Supply Chain Manag. 45, 18-25.

Lamming, R.C., Faruk, A.C., Cousins, P.D., 1999. Environmental soundness: a pragmatic alternative to expectations of sustainable development in business strategy. Bus. Strategy Environ. 8 (3), 177-188.

Laursen, K., Salter, A., 2006. Open for innovation: the role of openness in explaining innovation performance among U.K. manufacturing firms. Strateg. Manag. J. 27 (2)), 131-150

Lawson, B., Petersen, K.J., Cousins, P.D., Handfield, R.B., 2009. Knowledge sharing in inter-organizational product development teams: the effect of formal and informal socialization mechanisms. J. Prod. Innov. Manag. 26, 156-172.

Lewis, M.A., 2000. Lean production and sustainable advantage. Int. J. Oper. Prod. Manag. 20 (8), 959-978.

Lewis, M., Brandon-Jones, A., Slack, N., Howard, M., 2010. Competing through operations and supply-the role of classic and extended resource based advantage. Int. J. Oper. Prod. Manag. 30, 1032-1058.

Liefer, R., McDermott, C., O'Connor, G., Peters, L., Rice, M., Veryzer, R., 2000. Radical Innovation: How Mature Companies Can Outsmart Upstarts. Harvard Business School Press, Boston.

Lin, N., 2001. Social Capital: a Theory of Structure and Action. Cambridge University Press, London and New York.

Lincoln, J.R., 1982. Intra- and interorganizational networks. Res. Sociol. Organ. 1, $1-38$.

Linton, J.D., Klassen, R.B., Jayaraman, V., 2007. Sustainable supply chains: an introduction. J. Oper. Manag. 25 (6), 1075-1082.

Mayer, K.J., 2006. Spillovers and governance: an analysis of knowledge and reputational spillovers in information technology. Acad. Manag. J. 49 (1), 69-84.

McEvily, B., Zaheer, A., 1999. Bridging ties: a source of firm heterogeneity in competitive capabilities. Strateg. Manag. J. 20 (12), 1133-1156.

Michelfelder, I., Kratzer, J., 2013. Why and how combining strong and weak ties within a single interorganizational $\mathrm{R} \& \mathrm{D}$ collaboration outperforms other collaboration structures. J. Prod. Innov. Manag. 30, 1159-1177.

Miemczyk, J., Johnsen, T.E., Macquet, M., 2012. Sustainable purchasing and supply management: a structured literature review of definitions and measures at the dyad, chain and network levels. Supply Chain Manag. Int. J. 17 (5), 478-496.

Narasimhan, R., Narayanan, S., 2013. Perspectives on supply network-enabled innovations. J. Supply Chain Manag. 49, 27-42.

Nohria, N., Eccles, R., 1992. Face-to-face: making network organizations work. In: Nohria, N., Eccles, R. (Eds.), Networks and Organizations: Structure, Form, and Action. Harvard Business School Press, pp. 288-308.

Pagell, M., Wu, Z., 2009. Building a more complete theory of sustainable supply chain management using case studies of 10 exemplars. J. Supply Chain Manag. $45,37-56$.

Pennington, D.W., Potting, J., Finnveden, G., Lindeijer, E., Jolliet, O., Rydberg, T., Rebitzer, G., 2004. Life cycle assessment. Part 2. Current impact assessment practice. Environ. Int. 30, 721-739.

Penrose, E.T, 1959. The Theory of Growth of the Firm. Wiley, New York.

Perols, J., Zimmermanna, C., Kortmann, S., 2013. On the relationship between supplier integration and time-to-market. J. Oper. Manag. 31, 153-167.

Peteraf, M.A., 1993. The cornerstones of competitive advantage: a resource-based view. Strateg. Manag. J. 14 (3), 179-191.

Plieth, H., Bullinger, A.C., Hansen, E.G., 2012. Sustainable entrepreneurship in the apparel industry - the case of manomama. J. Corp. Citizsh. 45 (Spring), 121-134.

Porter, M.E., Kramer, 2011. The big idea: creating shared value. Harv. Bus. Rev. 89 $(1-2), 62-77$.

Prahalad, C.K. Hamel, G., 1990. The core competence of the corporation. Harvard Bus. Rev. 68 (3), 79-91.

Ragatz, G.L., Handfield, R.B., Petersen, K.J., 2002. Benefits associated with supplier integration into new product development under conditions of technological uncertainty. J. Bus. Res. 55, 389-400.

Rao, P., Holt, D., 2005. Do green supply chains lead to competitiveness and economic performance? Int. J. Oper. Prod. Manag. 25 (19), 898-916.

Rapoport, A., Horvath, W.J., October 1961. A study of a large sociogram. Behav. Sci. 6 , 279-291.

Rebitzer, G., Ekvall, T., Frischknecht, R., Hunkeler, D., Norris, G., Rydberg, T., Schmidt, W.-.P., Suh, S., Weidema, B.P., Pennington, D.W., 2004. Life cycle assessment. Part 1. Framework, goal and scope definition, inventory analysis, and applications. Environ. Int. 30, 701-720.

Rennings, K., Ziegler, A., Ankele, K., Hoffmann, E., 2006. The influence of different characteristics of the EU environmental management and auditing scheme on technical environmental innovations and economic performance. Ecol. Econ. 57, 45-59. 
Roome, N., 2001. Conceptualizing and studying the contribution of networks in environmental management and sustainable development. Bus. Strategy Environ. 10 (2), 69-76.

Roethlisberger, J., Dickson, W.J., 1939. Management and the Worker. Harvard University Press, Cambridge, Mass.

Sarkis, J., 2003. A strategic decision framework for green supply chain management. J. Clean. Prod. 11 (4), 397-409.

Savitz, A.W., Weber, K., 2006. The Triple Bottom Line. Jossey-Bass, San Francisco, CA. Seuring, S., Muller, M., 2008. From a literature review to a conceptual framework for sustainable supply chain management. J. Clean. Prod. 16, 1699-1710.

Shan, W., Walker, G., Kogut, B., 1994. Interfirm cooperation and startup innovation in the biotechnology industry. Strateg. Manag. J. 15, 387-394.

Sharma, S., Henriques, I., 2005. Stakeholder influences on sustainability practices in the Canadian forest products industry. Strateg. Manag. J. 26, 159-180.

Shin, H., Collier, D.A., Wilson, D.D., 2000. Supplier management orientation and supplier/buyer performance. J. Oper. Manag. 18, 317-333.

Simard, C., West, J., 2006. Knowledge networks and the geographic locus of innovation. In: Chesbrough, Henry, Vanhaverbeke, Wim, West, Joel (Eds.), Open Innovation: Researching a New Paradigm. Oxford University Press, Oxford, pp. 220-240.

Song, M., Di Benedetto, A.C., 2008. Supplier's involvement and success of radical new product development in new ventures. J. Oper. Manag. 26, 1-22.

Srivastava, S.K., 2007. Green supply-chain management: a state-of-the-art literature review. Int. J. Manag. Rev. 9, 53-80.

Stuart, T.E., Hoang, H., Hybels, R.C., 1999. Inter-organizational endorsements and the performance of entrepreneurial ventures. Adm. Sci. Q. 44, 315-349.

Teece, D., Pisano, G., Schuen, A., 1997. Dynamic capabilities and strategic management. Strateg. Manag. J. 18 (7), 509-533.

Touboulic, A., Chicksand, D., Walker, H., 2014. Managing imbalanced supply chain relationships for sustainability: a power perspective. Decis. Sci. 45 (4), 577-619.
Utterback, J.M., Abernathy, W.J., 1975. A dynamic model of process and product innovation. Omega 3 (6), 649-656.

Uzzi, B., 1997. Social structure and competition in interfirm networks: the paradox of embeddedness. Adm. Sci. Q. 42 (1), 35-67.

Vachon, S., Klassen, R.D., 2007. Supply chain management and environmental technologies: the role of integration. Int. J. Prod. Res. 45, 401-423.

van Bommel, H.W.M., 2011. A conceptual framework for analysing sustainability strategies in industrial supply networks from an innovation perspective. J. Clean. Prod. 19, 895-904.

Vanhaverbeke, W., 2006. The interorganizational context of open innovation. In: Chesbrough, Henry, Vanhaverbeke, Wim, West, Joel (Eds.), Open Innovation: Researching a New Paradigm. Oxford University Press, Oxford.

van Hemel, C., Cramer, J., 2002. Barriers and stimuli for eco-design in SMEs. J. Clean. Prod. 10, 439-453.

WCED (World Commission on Environment and Development), 1987. Our Common Future. Oxford University Press, Oxford.

Wernerfelt, B., 1984. A resource-based view of the firm. Strateg. Manag. J. 5 $171-180$.

Wenger, E., 1998. Communalities of Practice: Learning, Meaning and Identity. Cambridge Press, New York.

West, J., 2006. Does appropriability enable or retard open innovation? In: Chesbrough, H., Vanhaverbeke, W., West, J. (Eds.), Open Innovation: Researching a New Paradigm. Oxford University Press, Oxford, pp. 109-133.

Wilk, E.O., Fensterseifer, J.E., 2003. Use of resource-based view in industrial cluster strategic analysis. Int. J. Oper. Prod. Manag. 23 (9), 995-1010.

Yan, T., Dooley, K.J., 2013. Communication intensity, goal congruence, and uncertainty in buyer-supplier new product development. J. Oper. Manag. 31 (7), 523-542.

Zhu, Q., Sarkis, J., 2004. Relationships between operational practices and performance among early adopters of green supply chain management practices in Chinese manufacturing enterprises. J. Oper. Manag. 22 (3), 265-289. 